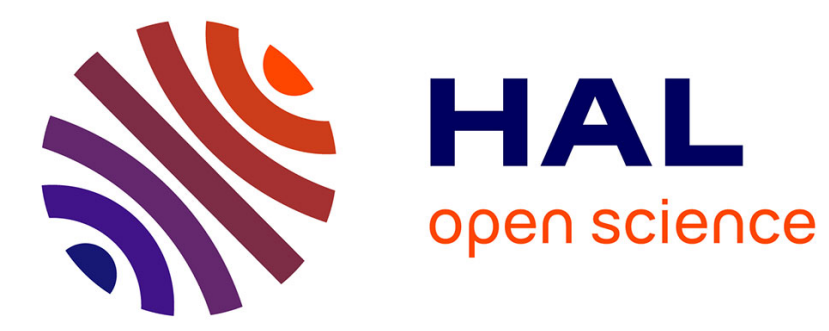

\title{
Exchange Rate Dynamics and Fundamental Equilibrium Exchange Rates
}

\author{
Jamel Saadaoui
}

\section{To cite this version:}

Jamel Saadaoui. Exchange Rate Dynamics and Fundamental Equilibrium Exchange Rates. Economics Bulletin, 2011, 31 (3), pp.1993-2005. halshs-00593674v3

\section{HAL Id: halshs-00593674 \\ https://shs.hal.science/halshs-00593674v3}

Submitted on 23 May 2011

HAL is a multi-disciplinary open access archive for the deposit and dissemination of scientific research documents, whether they are published or not. The documents may come from teaching and research institutions in France or abroad, or from public or private research centers.
L'archive ouverte pluridisciplinaire HAL, est destinée au dépôt et à la diffusion de documents scientifiques de niveau recherche, publiés ou non, émanant des établissements d'enseignement et de recherche français ou étrangers, des laboratoires publics ou privés. 


\title{
CEPN \\ Document de travail du CEPN N²011-06 \\ Exchange Rate Dynamics and Fundamental Equilibrium Exchange Rates
}

\author{
Jamel Saadaoui ${ }^{1}$
}

\begin{abstract}
The paper investigates if the most popular alternative to the purchasing parity power approach (PPP) to estimate equilibrium exchange rates, the fundamental equilibrium exchange rate (FEER) influences exchange rate dynamics in the long run. For a large panel of industrialized and emerging countries and on the period 1982-2007, we detect the presence of unit roots in the series of real effective exchange rates and in the series of FEERs. We find and estimate a cointegration relationship between real effective exchange rates and FEERs. The results show that the FEER has a positive and significant influence on exchange rate dynamics in the long run.
\end{abstract}

JEL Classification: F00; F31; F32; C23

Key Words: Fundamental equilibrium exchange rates; Panel unit root tests; Global imbalances; Fully modified ordinary least square; Dynamic ordinary least square; Pooled Mean Group

\footnotetext{
${ }^{1}$ University of Paris North, CEPN-CNRS, jamel.saadaoui@edu.univ-paris13.fr. The author is grateful to Jacques Mazier for its helpful comments and suggestions on earlier versions of the paper.
}

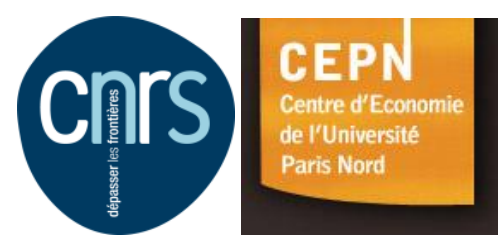




\section{Introduction}

The evolution of current account balances, which have considerably increased since the last fifteen years, has raised many questions. Among them, many observers (see e.g. Cline and Williamson, 2010) think that some countries (mainly South East Asian countries) have pursued aggressive exchange rate policy to maintain their currency at artificially low level in order to preserve their competitiveness on foreign markets. These politics of exchange rate undervaluation have allowed these countries to accumulate huge current account surplus. However as the misalignments (deviation from equilibrium exchange rate) offset each other at the world scale, if some countries are undervalued and run large current account surplus then some other countries are overvalued and run large current account deficits.

The paper investigates if the most popular alternative to the PPP approach to estimate equilibrium exchange rates, the FEER (Williamson, 1983, 1994) influences exchange rate dynamics in the long run. If the FEER affects the long run exchange rate dynamics, it can be considered as the 'true equilibrium exchange rate' and policy makers should pursue this rate to ensure global macroeconomic stability in a context of large imbalances.

As pointed out by Clark and MacDonald (1998), the notion of equilibrium in the FEER, which is a method of calculation of the equilibrium exchange rate consistent with external equilibrium (sustainable capital flows) and internal equilibrium (full utilization of productive potential), can be questioned if we consider that some variables which influence directly exchange rate behavior are often omitted in the calculations.

Zhou (1993) tests if the FEER affects exchange dynamics thanks to unit root tests and bivariate cointegration tests. She found empirical evidence that real effective exchange rates (REERs) and FEERs are unit roots process however she does not found that REERs and FEERs are cointegrated and, then, she concluded that exchange rate dynamics is not affected by the FEER.

These results can be misleading because they concerned only two countries (Japan and Germany) and a relatively short span of time (1974-1988) whereas the FEER approach is essentially a multilateral approach in which the global consistency, mentioned above, is crucial.

Barisone et alii (2006) study this question by using data for the G7 countries on the period 1973-1997. They implemented unit root tests, panel unit root tests and panel cointegration tests (Pedroni, 1999). They found empirical evidence that REERs and FEERs are unit roots process and, contrary to Zhou (1993), they found that REERs and FEERs are cointegrated.

For a large panel of industrialized and emerging countries and on the period 1982-2007, we detect the presence of unit roots in the series of REERs and in the series of FEERs. We find and estimate a cointegration relationship between REERs and FEERs. The results show that the FEER has a positive and significant influence on exchange rate dynamics in the long run.

The paper is organized as follow. Section 2 presents panel unit root tests. Section 3 tests a long run relationship between REERs and FEERs by using Pedroni's panel cointegration tests (1999). Section 4 estimates the long run relationship between REERs and FEERs by using the fully modified ordinary least square estimator (FMOLS) and the dynamic ordinary least square estimator (DOLS) introduced by Pedroni (2001). We also use a Pooled Mean Group (PMG) estimator introduced by Pesaran et alii (1999). Section 5 concludes. 


\section{Panel unit root tests for REERs and FEERs}

In this section, we implement a number of panel unit root tests for the series of REERs ${ }^{2}$ and for the series of FEERs of seventeen industrialized and emerging countries (the U.S., the U.K., the Euro area, Japan, Korea, China, Brazil, India, Mexico, Argentina, Chile, Colombia, Indonesia, Malaysia, Philippines, Thailand and Uruguay) and on the period 1982-2007.

The FEER is defined as the exchange rate prevailing when the economy simultaneously reaches the external equilibrium and the internal equilibrium for all the trading partners. This measure was derived from a standard world trade model in which all the variables are endogenous except the external equilibrium (sustainable current account determined by structural variables) and the internal equilibrium (full utilization of the productive potential). The external equilibrium is estimated with panel regression techniques. The internal equilibrium is reached when the output gap is closed ${ }^{3}$.

Table 1: Panel unit root tests

\begin{tabular}{|c|c|c|c|c|c|c|c|c|}
\hline Test: & $L L C$ & Breit. & $F \_A D F$ & $F \_P P$ & $L L C$ & Breit. & $F \_A D F$ & $F \_P P$ \\
\hline Difference: & No & No & No & No & Yes & Yes & Yes & Yes \\
\hline $\begin{array}{l}\text { Exogenous } \\
\text { variable: }\end{array}$ & $\begin{array}{c}\text { Constant, } \\
\text { Trend }\end{array}$ & $\begin{array}{c}\text { Constant, } \\
\text { Trend }\end{array}$ & $\begin{array}{c}\text { Constant, } \\
\text { Trend }\end{array}$ & $\begin{array}{c}\text { Constant, } \\
\text { Trend }\end{array}$ & None & None & None & None \\
\hline $\begin{array}{c}\text { Null } \\
\text { Hypothesis: }\end{array}$ & UR & UR & UR & UR & UR & UR & UR & UR \\
\hline Common UR: & Yes & Yes & No & No & Yes & Yes & No & No \\
\hline reer $_{i, t}$ & 0.5 & 2.7 & 27.3 & 27.9 & $-15.1 * * *$ & $-11.9 * * *$ & $267.4 * * *$ & $286.0 * * *$ \\
\hline feer $_{i, t}$ & -1.1 & 1.4 & 38.4 & $62.2 * * *$ & $-17.4 * * *$ & $-13.7 * * *$ & $312.8 * * *$ & $363.9 * * *$ \\
\hline
\end{tabular}

Notes: "UR" indicates the null hypothesis of the presence of unit root. The symbol *** indicates statistical stationarity at the 1 percent level. The table shows different panel unit root tests: Levin, Lin, and Chu (2002) (LLC); Breitung (2000); Maddala and $\mathrm{Wu}(1999)$ and Choi (2001) Fischer-type panel unit root tests (F_ADF and F_PP).

Source: authors' calculations.

As we can see in table 1, we detect the presence of unit root in the series of REERs and in the series of FEERs. The series are nonstationary in level and stationary in first difference. The REERs and FEERs are nonstationary I(1) series. As a series is I(1) if it achieves stationarity after first differencing. This result is confirmed by other empirical studies (Zhou, 1993, Barisone et alii, 2006).

\footnotetext{
${ }^{2}$ Source: Bank for International Settlements for the real effective exchange rate basis 100 in 2000 (annual average of monthly data).

${ }^{3}$ See Jeong et al. (2010), Aflouk et al. (2010). The methodology used is a synthesis of previous works on the FEER (Borowski and Couharde, (2003), Jeong and Mazier, (2003)) and of the Symmetric Matrix Inversion Method (SMIM) recently proposed by Cline (2008).
} 


\section{Testing a long run relationship between REERs and FEERs}

In order to test a long run relationship between REERs and FEERs, we can conduct either panel unit root tests on the difference between REERs and FEERs or panel cointegration tests (Pedroni, 1999).

As we have found that the series of REERs and the series of FEERs are nonstationary then if we found that the difference between these two series is stationary, it would mean that these series are cointegrated with a $(1 ;-1)$ coefficient. In this paper, we estimate the long run relationship between REERs and FEERs thanks to the FMOLS estimator and the DOLS estimator introduced by Pedroni (2001) so it is unnecessary to impose any value to the cointegration vector before the empirical estimation (Barisone et alii, 2006). As a robustness check, we use the Pooled Mean Group estimator PMG (Pesaran et alii, 1999). We test the following long run equation ${ }^{4}$ :

$$
\text { reer }_{i, t}=\alpha_{i}+\beta \text { feer }_{i, t}+\mu_{i, t}
$$

where variables in minuscule represents natural logarithms. As we can see in table 2, the null hypothesis of no cointegration is strongly rejected in all of the tests. These results show that there is a long run relationship between REERs and FEERs.

Table 2: Panel cointegration tests ${ }^{5}$

\begin{tabular}{|c|c|}
\hline \multicolumn{2}{|c|}{ Pedroni residual cointegration test (1999) } \\
\hline \multicolumn{2}{|c|}{ Null Hypothesis: No cointegration } \\
\hline Included observations & 442 \\
\hline Cross-sections included & 17 \\
\hline \multicolumn{2}{|c|}{ Alternative hypothesis: common AR coefficients (within-dimension) } \\
\hline Panel-v & $2.51 *$ \\
\hline Panel-rho & $-3.01 * * *$ \\
\hline Panel-PP & $-3.65 * * *$ \\
\hline Panel-ADF & $-3.98 * * *$ \\
\hline \multicolumn{2}{|c|}{ Alternative hypothesis: individual AR coefficients (between-dimension) } \\
\hline Group rho-Statistic & -0.99 \\
\hline Group PP-Statistic & $-3.22 * * *$ \\
\hline Group ADF-Statistic & $-5.82 * * *$ \\
\hline \multicolumn{2}{|c|}{$\begin{array}{l}\text { Notes: The symbols } * * * * \text { indicate statistical significance at the } 10 \text { percent and } 1 \text { percent levels, respectively. }{ }^{* * *} \text { Reject null } \\
\text { of nonstationarity even at the } 1 \% \text { level; *Reject null of nonstationarity at the } 10 \% \text { level. } \\
\text { Source: authors' calculations. }\end{array}$} \\
\hline \multicolumn{2}{|c|}{$\begin{array}{l}{ }^{4} \text { We do not include temporal trend as we want to test if REERs and FEERs are cointegrated without any } \\
\text { divergence (Barisone et alii, 2006). We use the natural logarithms of these variables in order to obtain directly } \\
\text { the elasticities. } \\
5 \text { In appendix A, we provide panel unit root tests (Pesaran, 2007) and panel cointegration tests (Westerlund, } \\
\text { 2007) which allows for cross section dependencies (i.e. existence of common shocks). }\end{array}$} \\
\hline
\end{tabular}


Before to proceeding to the next step which will consist to estimate explicitly this long run relationship. We have to conduct panel cointegration test (Pedroni, 1999) between the FEER and the REER since, as it is described in appendix B, the causal relationship is bi-directional i.e. the FEER causes the REER and the REER causes the FEER. We test the following long run equation:

$$
\text { feer }_{i, t}=\delta_{i}+\text { ereer }_{i, t}+\varepsilon_{i, t}
$$

As we can see in table 3, the null hypothesis of no cointegration is strongly rejected in all of the tests. These results show that there is a long run relationship between FEERs and REERs.

Table 3: Panel cointegration tests

\begin{tabular}{cc}
\hline \multicolumn{2}{c}{ Pedroni residual cointegration test (1999) } \\
\hline \multicolumn{2}{c}{ Null Hypothesis: No cointegration } \\
\hline Included observations & 442 \\
Cross-sections included & 17 \\
\hline Alternative hypothesis: common AR coefficients (within-dimension) \\
\hline Panel-v & 0.85 \\
Panel-rho & $-2.50^{* * *}$ \\
Panel-PP & $-3.38^{* * *}$ \\
Panel-ADF & $-3.39 * * *$ \\
\hline Alternative hypothesis: individual AR coefficients $($ between-dimension) \\
\hline Group rho-Statistic & $-1.59 *$ \\
Group PP-Statistic & $-4.06^{* * *}$ \\
Group ADF-Statistic & $-5.42^{* * *}$
\end{tabular}

Notes: The symbols $*$,*** indicate statistical significance at the 10 percent and 1 percent levels, respectively. $* * *$ Reject null of nonstationarity even at the $1 \%$ level; *Reject null of nonstationarity at the $10 \%$ level.

Source: authors' calculations.

\section{Estimation of the long run relationship between REERs and FEERs}

In this section, we implement the FMOLS estimator, the DOLS estimator and the PMG estimator to estimate the long run relationship between REERs and FEERs, as it is specified in equation (1) and equation (2). We use these econometric tools, introduced by Pedroni (2001) and Pesaran et alii (1999), in a context of nonstationarity of the series to avoid problems of fallacious regressions.

The results, in table 4 to 7 , indicate that the FEER has a positive and significant influence on exchange rate dynamics in the long run $^{6}$. In order to check the sensitivity to the results at the type of countries included in the panel, we re-estimate the equation (1) and equation (2) for emerging countries only, the results are largely similar.

\footnotetext{
${ }^{6}$ The FMOLS, DOLS and PMG estimations give similar results with a long run coefficient close to 0.6 for equation (1) and (2).
} 
Table 4: Long run relationship between REERs and FEERs
$F_{M O L S}^{1}$
$0.66 * * *$
24.06

DOLS $S^{2}$

$0.65 * * *$

29.37

$P M G^{3}$

$0.68 * * *$

11.05

Hausman test

0.15

0.70

Cross-section included

17

Number of Observations

442

Notes: (1) FMOLS is the Fully Modified OLS estimation; (2) DOLS is the Dynamic OLS estimation; (3) PMG is the Pooled Mean Group estimation. The symbol *** indicates statistical significance at the 1 percent level. The null hypothesis in the Hausman test is homogeneity of the long run coefficient in the PMG estimation.

Source: authors' calculations

Table 5: Long run relationship between REERs and FEERs (emerging countries only)

FMOLS $S^{1} \quad 0.68^{* * * *} \quad 22.28$

DOLS $S^{2} \quad 0.66^{* * *} \quad 26.72$

$P M G^{3} \quad 0.66^{* * *} \quad 10.04$

Hausman test

1.73

0.18 
Table 6: Long run relationship between FEERs and REERs
$F_{M O L S}^{1}$
$0.62 * * *$
23.26

$D O L S^{2}$

$0.62 * * *$

27.64

$P M G^{3}$

$0.65 * * *$

15.36

Hausman test

1.43

0.23

Cross-section included

17

Number of Observations

442

Notes: (1) FMOLS is the Fully Modified OLS estimation; (2) DOLS is the Dynamic OLS estimation; (3) PMG is the Pooled Mean Group estimation. The symbol *** indicates statistical significance at the 1 percent level. The null hypothesis in the Hausman test is homogeneity of the long run coefficient in the PMG estimation.

Source: authors' calculations

Table 7: Long run relationship between FEERs and REERs (emerging countries only)

\begin{tabular}{|c|c|}
\hline$F M O L S^{1}$ & $0.66 * * *$ \\
\hline
\end{tabular}

DOLS $S^{2} 0.66^{* * *} \quad 25.69$

$\begin{array}{lll}P M G^{3} & 0.71 * * * & 16.34\end{array}$
Hausman test
0.85
0.35 


\section{Conclusion}

We provide empirical evidence that the most popular alternative to the purchasing parity power approach (PPP) to estimate equilibrium exchange rates, the fundamental equilibrium exchange rate (FEER) influences exchange rate dynamics in the long run. For a large panel of industrialized and emerging countries and on the period 1982-2007, we detect the presence of unit roots in the series of real effective exchange rates and in the series of FEERs. We find and estimate a cointegration relationship between real effective exchange rates and FEERs.

The results show that the FEER has a positive and significant influence on exchange rate dynamics in the long run. Therefore it can be considered as the 'true equilibrium exchange rate' and policy makers should pursue this rate to ensure global macroeconomic stability in a context of large imbalances. 


\section{References}

Aflouk, N., Jeong, S.-E., Mazier, J. and Saadaoui, J. (2010) 'Exchange Rate Misalignments and World Imbalances: A FEER Approach for Emerging Countries', CEPN Working Paper No. 2010-12, Paris North University.

Breitung, J. (2000) 'The local power of some unit root tests for panel data', In B.H. Baltagi (Ed.) Advances in econometrics: Nonstationary panels, panel cointegration, and dynamic panels 15, Amsterdam: JAI Press.

Borowski, D. and Couharde, C. (2003) 'The Exchange Rate Macroeconomic Balance Approach: New Methodology and Results for the Euro, the Dollar, the Yen and the Pound Sterling', Open Economies Review 14 (2), 169-190.

Clark, P. B. and MacDonald, R. (1998) 'Exchange Rates and Economics Fundamentals: A Methodological Comparison of BEERs and FEERs', IMF Working Paper No. 98/67, International Monetary Fund.

Choi, I. (2001) 'Unit root tests for panel data', Journal of International Money and Finance 20, 249-272.

Cline, W. R. (2008) 'Estimating Consistent Fundamental Equilibrium Exchange Rates', Working Paper No. WP08-6, Peterson Institute for International Economics.

Cline, W. R. and Williamson, J. (2010) 'Currency Wars?', Policy Brief No. 10-26, Peterson Institute of International Economics.

Jeong, S.-E. and Mazier, J. (2003) 'Exchange Rate Regimes and Equilibrium Exchange Rates in East Asia', Revue économique 54 (5), 1161-1182.

Jeong, S.-E., Mazier, J. and Saadaoui, J. (2010) 'Exchange Rate Misalignments at World and European Level: A FEER approach', Économie Internationale / International Economics 121, 25-58.

Levin, A., Lin, C. -F. and C. -S. J. Chu (2002) 'Unit root tests in panel data: Asymptotic and finite sample properties', Journal of Econometrics 108, 1-22.

Maddala, G. and S. Wu (1999) 'A comparative study of unit root tests with panel data and a simple new test', Oxford Bulletin of Economics and Statistics 61, 631-652.

Pedroni, P. (1999) 'Critical Values for Cointegration Tests in Heterogeneous Panels with Multiple Regressors', Oxford Bulletin of Economics and Statistics 61, 653-70.

Pedroni, P. (2001) 'Purchasing Power Parity Tests in Cointegrated Panels', The Review of Economics and Statistics 83 (4), 727-731.

Persyn, D., Westerlund, J. (2008) 'Error correction based cointegration tests for panel data', Stata Journal 8, 232-241.

Pesaran, M. H., Y. Shin, R. P. Smith (1999) 'Pooled mean group estimation of dynamic heterogeneous panels', Journal of the American Statistical Association 94, 621-634.

Pesaran, M. H. (2007) 'A simple unit root test in the presence of cross section dependence', Journal of Applied Econometrics 22, 265-312.

Westerlund, J. (2007) 'Testing for error correction in panel data', Oxford Bulletin of Economics and Statistics 69, 709-748.

Williamson, J. (1983) 'The Exchange Rate System', Washington: Institute for International Economics.

Williamson, J. (1994) 'Estimating Equilibrium Exchange Rates', Washington: Institute for International Economics.

Zhou, S. (1993) 'Fundamental Equilibrium Exchange Rates and Exchange Rate Dynamics', Open Economies Review (4), 189-209. 


\section{Appendix A: Panel unit root tests and panel cointegration tests}

We use the CADF test introduced by Pesaran (2007) to test the unit root properties of the variables in presence of cross section dependencies. By subtracting cross section averages of lagged levels in addition to the standard ADF equation, this test is robust to cross section dependencies. The series are nonstationary I(1) series.

Table A1: Integration of the variables involved

\begin{tabular}{ccc}
\hline & Level & First Difference \\
\hline \multirow{2}{*}{ feer } & 0.223 & $-4.271 * * *$ \\
& $(0.806)$ & $(0.000)$ \\
reer & 0.375 & $-3.083 * * *$ \\
& $(0.646)$ & $(0.001)$ \\
\hline
\end{tabular}

Notes: The p-values are in parentheses. The symbol *** indicates statistical stationarity at the 1 percent level. Source: authors' calculations.

To test cointegration, the panel and group mean statistic suggested by Westerlund (2007) are applied. The existence of a negative and significant error correction term is taken as proof for cointegration. In case of cross section dependencies between members of the panel, critical values need to be obtained through bootstrapping. Results indicate that these variables are cointegrated.

Table A2: Cointegration of the variables involved

\begin{tabular}{ccccc}
\hline & $\mathrm{G} \tau$ & $\mathrm{G} \alpha$ & $\mathrm{P} \tau$ & $\mathrm{P} \alpha$ \\
\hline \multirow{2}{*}{ reer, feer } & $-2.162 * * *$ & $-6.414 * *$ & $-6.661 *$ & $-4.005 * *$ \\
& $(0.001)$ & $(0.013)$ & $(0.070)$ & $(0.031)$ \\
feer, reer & $-2.481 * * *$ & $-7.460 * * *$ & $-9.441 * * *$ & $-6.548 * * *$ \\
& $(0.000)$ & $(0.000)$ & $(0.001)$ & $(0.001)$ \\
\hline
\end{tabular}

Notes: The symbols *, **, *** indicate statistical significance at the 10 percent, the 5 percent and 1 percent levels, respectively. The p-value for cointegration tests are based on bootstrap methods, where 800 replications are used. See Persyn and Westerlund (2008) for the details.

Source: authors' calculations. 


\section{Appendix B: Panel Causality Tests}

We test the following relationship:

$$
\text { reer }_{i, t}=\alpha_{0 i}+\alpha_{1 i} \text { feer }_{i, t}+u_{i, t}
$$

where variables in minuscule represents natural logarithms. The $\operatorname{ARDL}^{7}$ equation $(1,1)$ associated with the above equation can be written:

$$
\text { reer }_{i, t}=\delta_{0 i}+\delta_{1 i} \text { feer }_{i, t}+\delta_{2 i} \text { feer }_{i, t-1}+\lambda_{i} \text { reer }_{i, t-1}
$$

We can rewrite equation (4) as follows:

$$
\Delta \text { reer }_{i, t}=\lambda_{i} \text { reer }_{i, t-1}-\text { reer }_{i, t-1}+\delta_{0 i}+\left(\delta_{1 i}+\delta_{2 i}\right) \text { feer }_{i, t}-\delta_{2 i} \Delta \text { feer }_{i, t}+\varepsilon_{i, t}
$$

The error correction equation yield:

$$
\Delta \text { reer }_{i, t}=\phi_{i}\left(\text { reer }_{i, t-1}-\theta_{0 i}-\theta_{1 i} \text { feer }_{i, t}\right)-\delta_{2 i} \Delta \text { feer }_{i, t}+\varepsilon_{i, t}
$$

with $\phi_{i}=-\left(1-\lambda_{i}\right) ; \theta_{0 i}=\delta_{0 i} /\left(1-\lambda_{i}\right) ; \theta_{1 i}=\left(\delta_{1 i}+\delta_{2 i}\right) /\left(1-\lambda_{i}\right)$

Since the PMG estimator imposes long-run coefficients to be constant for all individuals, while it allows short run heterogeneity, the error correction model is written:

$$
\begin{aligned}
& \Delta \text { reer }_{i, t}=\phi\left(\text { reer }_{i, t-1}-\theta_{0}-\theta_{1} \text { feer }_{i, t}\right)-\delta_{2 i} \Delta \text { feer }_{i, t}+\varepsilon_{i, t} \\
& \Delta \text { feer }_{i, t}=\phi\left(\text { feer }_{i, t-1}-\theta_{0}-\theta_{1} \text { reer }_{i, t}\right)-\delta_{2 i} \text { seer }_{i, t}+\varepsilon_{i, t}
\end{aligned}
$$

We estimate two reciprocal equations for causality test with the PMG estimator (i.e. we test if the REER causes the FEER and if the FEER causes the REER). The decision rule is: when the error correction term is negative and significant then the null hypothesis of no causality is rejected.

Table B1: Panel Causality Tests

Error-corrections coefficient $(\phi)$

\begin{tabular}{cc}
\hline FEER $\rightarrow$ REER & $-0.24 * * *(-7.30)$ \\
\hline REER $\rightarrow$ FEER & $-0.38 * * *(-6.37)$ \\
\hline Number of Observations & 442 \\
\hline
\end{tabular}

Notes: t-statistics in parentheses: $* * *$ significant at 1 percent.

Source: authors' calculations.

${ }^{7}$ Autoregressive Distributed Lags 
Table B2: Panel Causality Tests (emerging countries only)

\begin{tabular}{cc}
\hline & Error-corrections coefficient $(\phi)$ \\
\hline FEER $\rightarrow$ REER & $-0.27 * * *(-7.74)$ \\
\hline REER $\rightarrow$ FEER & $-0.42 * * *(-6.05)$ \\
\hline Number of Observations & 338 \\
\hline
\end{tabular}

Notes: t-statistics in parentheses: $* * *$ significant at 1 percent.

Source: authors' calculations.

We can conclude that:

- The no causality hypothesis is strongly rejected in all cases

- The error-correction coefficients ( $\phi$ 's) are negative and statistically significant, indicating the causal relationship is bi-directional.

- These relationships are robust to the types of countries. 